\title{
PEMURNIAN SISTEM PRESIDENSIL DAN PARLEMEN DUA KAMAR DI INDONESIA SEBAGAI GAGASAN PERUBAHAN UUD 1945
}

\author{
Harry Setya Nugraha \\ Program Pascasarjana Fakultas Hukum Universitas Islam Indonesia \\ Jl. Cikditiro No. 1 Kota Baru Yogyakarta \\ Email: Harrysn22@gmail.com
}

\begin{abstract}
Abstrak
Dalam tatanan ideal, konstitusi suatu negara haruslah sejalan dengan nilai-nilai konstitusionalisme. Namun realitanya saat ini, konstitusi negara Indonesia (UUD NRI 1945) masih belum sejalan dengan nilai-nilai konstitusionalisme itu sendiri. Hal ini dapat dilihat dari biasnya bangunan presidensialisme di Indonesia serta tidak jelasnya sistem kamar parlemen yang diterapkan di Indonesia, apakah berkayuh pada sistem parlemen tiga kamar ataukah pada sistem parlemen dua kamar. Tulisan hukum ini ditulis untuk mengkaji bagaimana desain ideal sistem pemerintahan presidensil dan kamar parlemen di Indonesia. Pada bagian akhir tulisan hukum ini, disimpulkan bahwa terdapat 5 gagasan yang perlu menjadi materi perubahan dalam UUD NRI 1945 dalam rangka mewujudkan sistem presidensil yang lebih murni. Selain itu, dalam upaya mempertegas parlemen dua kamar di Indonesia, langkah pertama yang harus dilakukan adalah merubah paradigma MPR yang semula dianggap sebagai sebuah lembaga yang memiliki keanggotaan tersendiri, menjadi MPR yang merupakan forum sidang gabungan antara DPR dan DPD. Selanjutnya, agar sistem parlemen dua kamar yang digagas menjadi lebih ideal, DPR dan DPD haruslah diposisikan dalam strata yang sama dalam hal fungsi dan kewenangannya
\end{abstract}

Kata Kunci: Perubahan Kelima UUD NRI 1945; Sistem Presidensil; Parlemen dua kamar.

\section{ABSTRACT}

In the ideal order, constitution of a state must be harmonized with the values of constitutionalism. However, in the reality today, Indonesian Constitution (The 1945 Constitution of the Republic of Indonesia) is still not in line with the values of constitutionalism. It can be viewed from the bias of Presidentialism construction in Indonesia and the ambiguity of the parliamentary chamber system, whether it is based on the three chambers parliamentary system or on the two chambers parliamentary system. This study reviews on how is the ideal design of presidential system of government and parliamentary chamber in Indonesia. The final section of this article concluded that there are 5 notions in which need to be put into the material changes in the 1945 Constitution to incarnate the purer presidential system. Furthermore, to emphasize the two chambers parliament in Indonesia, the first step that must be 
undertaken is to change the paradigm of the MPR which at first considered as an institution that has its own membership, which is a joint session forum between DPR and DPD. Additionally, to make the initiated two chambers of parliament more ideal, $D P R$ and DPD must be positioned in equal strata in terms of the function and authority.

Keywords: Fifth Amendment of UUD NRI 1945, Presidential System, Two chambers of parliamentary

\section{A. PENDAHULUAN}

Mengawali tulisan hukum ini, terdapat beberapa hal yang perlu disampaikan oleh penulis. Pertama, bahwa menjadi keniscayaan suatu negara mempunyai peraturan dasar negara (konstitusi) yang diubah seiring dengan perubahan dinamika suatu negara sebagai implikasi dari ketidaksempurnaan konstitusi yang dimiliki oleh setiap negara. Kedua, bahwa dengan konstitusi yang jauh lebih sempurna pun belumlah cukup menjamin bahwa implementasi dari mandat konstitusi bisa dijalankan sebagaimana rumusan substantifnya.

Menyadari ketidaksempurnaan tersebut, dalam pemikiran yang paling sederhana, konstitusi sebagai kontrak sosial politik haruslah memiliki konstruksi konstitusionalisme yang menegaskan pembatasan kekuasaan dan jaminan hak rakyat melalui implementasi dari konstitusi itu sendiri. Oleh karenanya untuk menentukan kemana konstitusi menjadi lebih baik, tidaklah cukup jika hanya melalui proses yang demokratis dengan menggali akar kesejahteraan sosial, ekonomi, budaya, dan politik suatu bangsa, melainkan juga harus mampu memberikan ruang transformatif yang cukup guna membangun karakter konstitusionalisme.

Menurut Carl J. Friedrich dalam bukunya yang berjudul Constitutional Government and Democracy, konstitusionalisme mengandung gagasan bahwa pemerintahan yang diselenggarakan oleh dan atas nama rakyat dikenakan beberapa pembatasan yang diharapkan akan menjamin bahwa kekuasaan yang diselenggarakan tidak disalahgunakan oleh mereka yang mendapat tugas untuk memerintah (Marzuki, 2010: 4). Oleh karenanya, persoalan yang dianggap penting dan menjadi ruh dalam setiap konstitusi adalah pengaturan mengenai pengawasan atau pembatasan terhadap kekuasaan pemerintahan (Asshidiqie, 2011: 18). Pemberlakuan paham konstitusionalisme dalam konstitusi, setidaknya perlu mengadopsi beberapa hal: (1) Sistem Separation of Power atau Distribution of Power yang disertai checks and balances; (2) Sistem Kekuasaan Peradilan yang merdeka dan mandiri, utamanya lebih memberdayakan peradilan adminstrasi; (3) Pengakuan hak-hak sipil dan politik warga, utamanya yang berkaitan dengan pemilihan umum dan pemilukada; (4) Pembatasan masa jabatan-jabatan publik dalam negara; (5) Memberikan kewenangan pengaduan konstitusional (constitutional complaint) bagi Mahkamah Konstitusi.

Lebih lanjut konsensus yang menjamin tegaknya konstitusionalisme di zaman modern pada umumnya dipahami bersandar pada tiga elemen kesepakatan (consensus), yaitu: pertama kesepakatan tentang tujuan atau cita-cita bersama (the 
general goals of society or general acceptance of the same philosophy of government). Kedua kesepakatan tentang the rule of law sebagai landasan pemerintahan atau penyelenggaraan negara (the basis of government). ketiga kesepakatan tentang bentuk institusi-institusi dan prosedur-prosedur ketatanegaraan (the form of institutions and procedures) (Asshidiqqie, 2011:18).

Inilah yang kemudian menjadi dasar bahwa konstitusi sebenarnya tidak dapat terlepas dari konsep konstitusionalisme (Buiardjo, 2008: 21). Artinya dapat dipahami bahwa konstitusi haruslah berdasarkan konstitusionalisme, atau dengan kata lain konstitusi yang ideal adalah konstitusi yang mampu memuat pengaturan mengenai pengawasan atau pembatasan kekuasaan pemerintah secara tegas. Hal ini diperkuat oleh Harjono (2008: 21) yang menganalogikan konstitusi laksana bangunan rumah, sedang konstitusionalisme adalah ilmu arsitektur atau teknik sipilnya. Dengan demikian, secara sederhana dapat disimpulkan bahwa konstitusi adalah produk konstitusionalisme, sementara konstitusionalisme merupakan teori atau doktrin tentang konstitusi itu sendiri.

Namun realitanya saat ini, konstitusi negara Indonesia yakni Undang-Undang Dasar Negara Republik Indonesia (UUD NRI) 1945 masih jauh dari ruh konstitusionalisme itu sendiri, meskipun dalam perjalanannya telah mengalami perubahan sebanyak 4 (empat) kali yakni pertama pada tahun 1999, kedua tahun 2000, ketiga tahun 2001, dan perubahan keempat tahun 2002. Bahkan yang sangat disayangkan adalah dalam praktik ketatanegaraan selama berlakunya UUD NRI 1945 justru membawa negara Indonesia ke dalam otoritarianisme politik dan pengabaian terhadap prinsip-prinsip negara hukum (MPR, 2004:12).

Sebagai contoh, sebelum terjadinya proses perubahan, banyak ahli yang menyebut bahwa konstitusi kita menganut paham excecutive heavy. (Mahfudz MD, 2004: 7) Oleh karena itu perubahan dilakukan dengan maksud untuk membatasi kekuasaan eksekutif agar tidak terlalu dominan, namun ternyata substansi perubahan yang telah dilakukan sebanyak 4 (empat kali) tersebut hanya menggeser paham excecutive heavy menjadi legislative heavy. Secara prosedural perubahan berhasil dilakukan. Namun dari segi substansi, ruh konstitusionalisme sebagai tujuan perubahan gagal terwujudkan.

Hal ini dibuktikan dengan betapa besarnya kewenangan yang dimiliki oleh Dewan Perwakilan Rakyat (DPR) yang ternyata jika ditelusuri sangat berimplikasi terhadap bangunan sistem presidensialisme yang dianut oleh bangsa Indonesia. Sebut saja terkait kewenangan DPR dalam hal memberikan pertimbangan guna menerima penempatan duta negara lain. Pada ketentuan Pasal 13 ayat (3) UUD NRI 1945 menyebutkan "Presiden menerima penempatan duta negara dengan memperhatikan pertimbangan Dewan Perwakilan Rakyat". Biasanya kewenangan menerima duta negara lain adalah domain eksekutif atau Presiden, maka ketentuan adanya pertimbangan DPR menunjukkan dominasi kekuasaan DPR yang telah memasuki domain Presiden (Albert Hasibuan, "Politik: Perubahan ke 5 UUD", http://www.slideshare.net/AritonagKurus/perubahan-kelima-uud-1945, diakses pada 1 Desember 2016). Hal tersebut membuat konsep presidensial yang dianut 
oleh negara Indonesia menjadi bias dan kemudian membuat tidak sedikit ahli yang mengatakan bahwa sistem pemerintahan yang dianut oleh Indonesia adalah sistem "presidensil rasa parlemen". Dalam bahasa yang lebih ilmiah, disebut sebagai sistem "kuasi”.

Tidak hanya itu, permasalahan tidak dielaborasinya konsep konstitusionalisme ke dalam UUD NRI 1945 juga terlihat pada bangunan kamar parlemen dalam sistem ketatanegaraan Indonesia. Hasil perubahan yang "memangkas" beberapa kewenangan penting MPR sekaligus membuatnya tidak lagi ditempatkan sebagai lembaga negara tertinggi menambah kegalauan kita tentang jawaban atas pertanyaan, apakah Indonesia menggunakan dua kamar parlemen (bicameral) atau justru tiga kamar parlemen (trikameral)? Alhasil, tidak sedikit ahli yang kemudian berspekulasi dengan mengatakan bahwa Indonesia menggunakan sistem Soft Bicameral dalam sistem ketatanegaraanya. Permasalahan sebagaimana terurai, menurut penulis merupakan suatu hal yang tidak boleh dipandang sebelah mata, perlu sekiranya dilakukan upaya untuk merubah UUD NRI 1945 dengan memperkuat sistem pemerintahan Presidensil di Indonesia dan memperjelas bangunan kamar parlemen Indonesia.

\section{B. PEMBAHASAN}

\section{Gagasan Pemurnian Sistem Pemerintahan Presidensil}

Sebelum kita berbicara mengenai gagasan tentang pemurnian sistem presidensil di Indonesia, perlu kita pahami terlebih dahulu beberapa ciri khusus suatu negara dapat dikategorikan sebagai negara yang menggunakan sistem pemerintahan Presidensil.

Menurut ilmu ketatanegaraan, ada beberapa ciri-ciri khusus di mana suatu negara dikatakan menganut sistem presidensial. Adapun ciri sistem presidensial tersebut adalah: (1) Presiden adalah Kepala Negara dan Kepala Pemerintahan; (2) Presiden tidak dipilih oleh parlemen, tetapi langsung dipilih langsung oleh rakyat (popular elected); (3) Presiden bukan bagian dari parlemen, dan tidak dapat diberhentikan oleh parlemen, kecuali melalui proses pemakzulan (impechment); dan (4) Presiden tidak dapat membubarkan parlemen (Indrayana, 2008: 198).

Apabila ciri tersebut kita benturkan dengan sistem pemerintahan yang sedang dijalankan oleh negara Indonesia, maka benarlah adanya bahwa negara Indonesia menggunakan sistem pemerintahan Presidensil. Hal ini secara sederhana dapat dilihat dari empat sisi: (1) Presiden Indonesia berkedudukan sebagai Kepala Negara sekaligus Kepala Pemerintahan; (2) Presiden Indonesia tidak dipilih oleh parlemen, melainkan diplih langsung oleh rakyat; (3) Presiden Indonesia bukan bagian dari parlemen dan tidak dapat diberhentkan oleh parlemen; dan (4) Presiden Indonesia tidak dapat membubarkan parlemen. Namun pertanyaan yang kemudian muncul adalah apakah instrumen hukum yang ada saat ini telah mendukung pelaksanaan sistem Presidensial tersebut secara ideal?

Sebagaimana diketahui bahwa kesepakatan para pendiri negara (founding fathers) untuk menjalankan pemerintahan menggunakan sistem presidensial 
memberikan konsekuensi bahwa eksekutif (presiden) diposisikan sebagai satu institusi penyelenggara kekuasaan negara tertinggi di bawah Undang-Undang Dasar. Ada beberapa alasan yang mendasari penggunaan sistem presidensial oleh para pendiri negara (founding fathers) antara lain: (1) Untuk menjaga stabilitas pemerintahan; (2) Memperkuat posisi dan dominasi Presiden yang ditegaskan dalam UUD NRI 1945; (3) Negara yang baru merdeka tidak cukup pengetahuan; dan (4) Adanya pengaruh ketokohan Soekarno dan sistem Moh. Hatta (Saraswati, 2012: 139).

Menelisik dari aspek sejarahnya, diketahui bahwa sebelum terjadinya proses perubahan, sistem presidensial Indonesia dijalankan dengan tidak begitu tegas. Hal ini dikarenakan Presiden tidak dipilih langsung oleh rakyat, melainkan dipilih oleh MPR dan berkewajiban mempertanggungjawabkan hasil kerjanya kepada MPR. Sifat pertanggungjawaban kepada MPR tersebut memperlihatkan adanya unsur parlementer dalam sistem pemerintahan presidensial yang dianut negara Indonesia ketika itu (Asshiddiqie, "Institute Peradaban dan Gagasan Penguatan Sistem Pemerintahan",http://www.jimly.com/makalah/namafile/123/SISTEM PRESIDENT IL.pdf, diakses pada 2 Agustus 2016).

Namun sejak konstitusi diubah (tepatnya perubahan ketiga), presidensialisme di Indonesia sudah lebih murni. Dikatakan lebih murni karena Presiden yang semula dipilih oleh MPR, kini beralih dipilih oleh rakyat dan tidak pula memiliki tanggungjawab untuk mempertanggungjawabkan hasil kerjanya kepada MPR.

Pergeseran sistem pemerintahan yang demikian itu membawa perubahan yang juga begitu drastis dalam sistem ketatanegaraan Indonesia. Namun disayangkan, perubahan yang penulis maksud bukan ke arah suatu perbaikan, melainkan kearah otoritarianisme kekuasaan yang berujung pada dikesampingkannya nilai-nilai hukum dan kemanusiaan.

Besarnya kewenangan yang dimiliki oleh Presiden dalam sistem Presidensil tanpa dibarengi dengan kontrol yang baik dari legislatif maupun yudikatif dalam kenyataannya telah menimbulkan suatu kesewenang-wenangan (abuse of power). Misalnya di era Soeharto, sebagai pemegang tampuk kekuasaan tertinggi Soeharto sangat otoriter dalam memimpin. Presiden Soeharto pernah menjabat sebagai Presiden selama 30 tahun. Selama masa jabatannya tersebut, kekuasaan Presiden begitu besar tanpa adanya kontrol yang begitu berarti dari cabang kekuasaan yang lainnya, sehingga UUD NRI 1945 sebelum perubahan sering disebut sebagai executive heavy (Suharto, 2006: 110).

Berlandaskan pada realita, maka para penyelenggara negara ketika itu menyadari akan perlunya suatu kontrol terhadap Presiden agar tidak terjadi abuse of power. Selanjutnya, semangat untuk mengontrol Presiden ini diwujudkan melalui perubahan UUD NRI 1945. Namun, ternyata hasil perubahan tersebut memberikan kekuasaan yang sangat besar kepada DPR, khususnya setelah perubahan keempat. Sehingga yang terjadi adalah pergeseran dari executive heavy menjadi legislative heavy. Dengan hasil perubahan yang demikian itu, justru memberikan dampak tereduksinya sistem presidensial yang dianut oleh negara Indonesia. 
DPR seakan menumpahkan seluruh dendam dan serapahnya karena hampir 32 tahun (1966-1998) dikekang dan berada di bawah komando eksekutif (Presiden) (http://repository.usu.ac.id/bitstream/123456789/18016/4/Chapter\%20I.pdf), diakses pada 2Agustus 2016). Secara lebih jelas, yang dimaksud legislative heavy dapat dilihat dari beberapa pasal-pasal dalam UUD NRI 1945 yang mengindikasikan kekuasaan DPR terlalu dominan, di antaranya yaitu Pasal 11 ayat (1) dan (2), Pasal 13, Pasal 14 ayat (2), Pasal 20 ayat (1), dan Pasal 20 ayat (5).

Tidak hanya itu, sangat banyak hak interpelasi yang digunakan oleh legislatif untuk mengkritisi kebijakan pemerintah. Kegiatan untuk meminta keterangan kepada Presiden yang terangkum dalam hak interpelasi DPR tersebut menurut hemat penulis mengindikasikan adanya subordinate antara DPR dengan Presiden, sehingga seolah-olah terkesan kedudukan DPR berada di atas Presiden.

Konteks yang lain, UUD NRI 1945 juga memberikan kewenangan legislasi kepada Presiden sebagaimana amanat Pasal 20 ayat (2) yang berbunyi "Setiap rancangan undang-undang dibahas oleh DPR dan Presiden untuk mendapat persetujuan bersama". Hal ini tentu tidak relevan dengan sistem presidensil.

Meskipun tidak dapat dipungkiri bahwa sistem presidensil dalam UUD NRI 1945 sudah lebih murni, namun dalam menjalankan kewenangannya, konstitusi tidak menjelaskan kapan Presiden diposisikan sebagai Kepala Negara dan kapan pula diposisikan sebagai Kepala Pemerintahan. Konstitusi hanya menyebutkan posisi Presiden sebagai kepala Pemerintahan (Pasal 4 ayat 1), tidak menyebutkan posisi Presiden sebagai Kepala Negara. Oleh karena itu, penguatan sistem Presidensil melalui perubahan kelima UUD NRI 1945 perlu dilakukan. Hal ini sejalan dengan salah satu butir kesepakatan dasar yang disusun oleh Panitia Ad Hoc (PAH) I dalam pembahasan perubahan UUD NRI 1945, yaitu mempertegas sistem pemerintahan presidensial (Siahan, 2012: 254).

Kesepakatan dasar untuk mempertegas sistem pemerintahan presidensil bertujuan untuk memperkukuh sistem pemerintahan yang stabil dan demokratis yang dianut oleh Negara Republik Indonesia dan telah dipilih oleh pendiri negara pada tahun 1945 (Huda, 2008: 207). Penguatan sistem presidensial usulan penulis tidak bermaksud untuk mengembalikan Indonesia pada rezim yang otoriter dengan memberikan kewenangan yang lebih kepada Presiden, melainkan untuk menyeimbangkan kekuasaan yang dimiliki Presiden sebagai Eksekutif dan DPR sebagai Legislatif. Sehingga tidak terjadi lagi feenomena legislative heavy maupun executive heavy.

Sebagai upaya penguatan sistem presidensil tersebut, penulis mengusulkan lima usulan untuk kemudian dirumuskan menjadi pasal-pasal dalam gagasan perubahan ulang, di antaranya adalah: pertama, mencabut kewenangan legislasi yang dimiliki Presiden. Kewenangan legislasi yang dimaksud adalah kewenangan badan legislatif dalam membentuk dan membahas undang-undang yang menjadi kewenangannya secara mutlak. Hal ini sejalan dengan ciri sistem Presidensil yang menyebutkan bahwa Presiden bukan merupakan bagian dari parlemen dan di perkuat oleh teori Trias Politica yang menyebutkan bahwa "ketiga jenis cabang 
kekuasaan, baik eksekutif, legislatif dan yudikatif haruslah terpisah satu sama lain, baik mengenai tugas (fungsi) maupun mengenai alat perlengkapan (organ) yang menyelengarakannya (Budiardjo, 2008: 282). Sehingga, menghilangkan fungsi legislasi dari diri Presiden merupakan pilihan yang dianggap tepat dalam rangka memperkuat sistem Presidensil di Indonesia. Namun agar terdapat suatu mekanisme check and ballance antara Presiden dan DPR dalam melaksanakan fungsi legislasi, Presiden diberikan hak veto atas rancangan undang-undang yang telah disetujui oleh DPR. Pembahasan lebih lanjut mengenai hak veto akan dibahas dalam pembahasan berikut ini.

Kedua, Presiden diberikan hak veto dalam pengesahan undang-undang. Gagasan ini berangkat dari kegelisahan penulis terhadap Pasal 20 ayat 5 UUD NRI 1945 yang menegaskan bahwa "Dalam hal rancangan undang-undang yang telah disetujui bersama tersebut tidak disahkan oleh Presiden dalam waktu tiga puluh hari semenjak rancangan undang-undang tersebut disetujui, rancangan undangundang tersebut sah menjadi undang-undang dan wajib diundangkan". Bunyi pasal tersebut memberikan pengertian bahwa Presiden tidak mempunyai alternatif lain selain menyetujui RUU yang diajukan oleh DPR.

Berkaitan dengan hal tersebut, perlu diketahui bahwa proses legislasi menurut rumusan UUD NRI 1945 dilakukan oleh dua institusi politik secara bersama, yaitu DPR dan Presiden. Pasal 20 ayat (1) UUD NRI 1945 menyebutkan bahwa "Dewan Perwakilan Rakyat memegang kekuasaan membentuk UndangUndang." Pada Pasal 5 ayat (1) disebutkan "Presiden berhak mengajukan rancangan undang-undang kepada Dewan Perwakilan Rakyat." Dan Pasal 20 ayat (2) menyebutkan bahwa, "Setiap Undang-Undang dibahas oleh Dewan Perwakilan Rakyat dan Presiden untuk mendapatkan persetujuan bersama".

Melalui ketiga Pasal tersebut, secara implisit dapat dimaknai bahwa baik Presiden maupun DPR pada dasarnya memiliki hak untuk menolak suatu rancangan undang-undang yang tidak sesuai dengan harapan. Hak inilah yang kemudian akrab dikenal dengan sebutan hak veto dalam proses legislasi. Ini terlihat dari kalimat "mendapat persetujuan bersama" pada Pasal 20 ayat (2) UUD NRI 1945.

Mengutip apa yang disampaikan oleh Parialis Akbar, ketiga pasal tersebut dapat dimaknai bahwa (Akbar, 2013:201):

1. Kekuasaan Legislasi DPR sepenuhnya tidak men-downgrade kewenangan legislasi Presiden, karena Presiden masih diberikan hak untuk mengajukan RUU dan membahas bersama suatu rancangan undang-undang.

2. Baik DPR maupun Presiden memiliki hak veto, yakni dalam bentuk menolak melakukan pembahasan dan persetujuan RUU di DPR selalu diwakili oleh para pembantunya atau kementrian/lembaga yang ditunjuk. Perintah Presiden bisa juga berupa penolakan untuk membahas suatu RUU. Namun bagi DPR yang fraksinya berasal dari partai yang memerintah, tentu akan menjadi masalah tersendiri karena harus menempuh kompromi bahkan voting dalam memutuskan penolakan pembahasan bersama sebuah RUU. 
3. Hak veto bukanlah suatu yang diharamkan bahkan sangat dimungkinkan dalam suatu negara demokrasi yang ditempuh melalui prosedur demokrasi itu sendiri.

Menanggapi hal tersebut, jika hak veto Presiden ditempatkan hanya dalam proses pengesahan rancangan undang-undang, tentu hak tersebut menjadi suatu hal yang ada namun seolah-olah tidak ada. Bahasa Arab menyebutnya "wujuduhu ka adamihi" (ada tetapi seolah-olah tidak ada). Mengapa demikian, sebab, konsepsi "pengesahan" sebagaimana termuat di dalam Pasal 20 ayat (5) UUD NRI 1945 hanya bersifat administratif belaka (Yuda, 2010: 259). Artinya, tanpa adanya pengesahan dari Presiden pun suatu rancangan undang-undang akan tetap menjadi undangundang setelah melewati batas waktu yang telah ditentukan.

Untuk itu, definisi hak veto dalam gagasan yang penulis ajukan haruslah dimaknai sebagai hak yang tidak hanya ditempatkan pada proses pengesahan yang sifatnya administrasi belaka, melainkan di balik ketidakmauan Presiden mengesahkan suatu rancangan undang-undang menjadi undang-undang terdapat akibat hukum yang mengikat bagi si pembuat undang-undang. Artinya, undangundang tersebut harus dibahas kembali oleh legislatif untuk kembali mendapatkan persetujuan bersama di antara mereka.

Agar Presiden tidak semena-mena dalam mengunakan hak vetonya, hak veto tersebut dapat ditolak oleh DPR dengan persyaratan tertentu, salah satunya adalah dengan dukungan mayoritas DPR sekitar dua per tiga suara parlemen. Sebagai contoh hak veto Presiden dalam konstruksi presidensialisme seperti Amerika Serikat. Presiden secara jelas mempunyai hak veto dalam proses pengesahan undang-undang. Presiden dapat menggunakan hak veto untuk menolak rancangan undang-undang yang telah diputuskan parlemen. Namun, parlemen juga dapat menganulir veto (override) dengan dukungan mayoritas kongres (Senate dan House of Representative), sekitar dua pertiga suara di parlemen. Jika setelah voting ternyata Kongres menyatakan rancangan undang-undang tersebut harus disahkan, Presiden wajib mengesahkannya menjadi undang-undang (Yuda, 2010: 259).

Beberapa gagasan lain yang masih berkenaan dengan hal ini, pertama dalam melakukan veto, Presiden harus menyertakan alasan-alasan keberatannya secara jelas kepada DPR; dan kedua Presiden diberikan waktu selambat-lambatnya 30 hari dalam melakukan pengkajian terhadap hasil rancangan undang-undang yang dilakukan oleh DPR. Pemberian jangka waktu selama 30 hari ini dengan rasionalisasi bahwa karena Presiden harus menimbang dan menilai rancangan undang-undang yang telah disetujui DPR serta harus menyerap aspirasi rakyat dalam menilaian rancangan undang-undang tersebut. Melihat beban Presiden tersebut maka sangat logis sekiranya apabila Presiden diberikan waktu 30 hari, sebab tidak singkat dan tidak terlalu lama. Dengan demikian jelaslah bahwa pemberian hak veto kepada Presiden di sini untuk mempertegas pemisahan kekuasaan (sparation of power) antara legislatif dengan eksekutif.

Dari beberapa usulan perubahan pada Pasal 20 UUD NRI 1945, penulis mencoba mengkonversinya ke dalam bahasa perundang-undangan sebagai berikut: 


\begin{tabular}{|c|c|}
\hline$\underline{\text { Ius Cons }}$ & Ius Constituendum: \\
\hline Pasal 20 & Pasal 20 \\
\hline $\begin{array}{l}\text { (1) Dewan Perwakilan Rakyat } \\
\text { memegang kekuasaan membentuk } \\
\text { undang-undang. }\end{array}$ & $\begin{array}{l}\text { (1) Dewan Perwakilan Rakyat } \\
\text { memegang kekuasaan membentuk } \\
\text { undang-undang. }\end{array}$ \\
\hline $\begin{array}{l}\text { (2) Setiap rancangan undang-undang } \\
\text { dibahas oleh Dewan Perwakilan } \\
\text { Rakyat dan Presiden untuk mendapat } \\
\text { persetujuan bersama. }\end{array}$ & $\begin{array}{l}\text { (2) Setiap rancangan undang-undang } \\
\text { memerlukan persetujuan Dewan } \\
\text { Perwakilan Rakyat dan mendapat } \\
\text { pengesahan Presiden untuk } \\
\text { menjadi undang-undang. }\end{array}$ \\
\hline $\begin{array}{l}\text { (3) Jika rancangan undang-undang itu } \\
\text { tidak mendapat persetujuan } \\
\text { bersama, rancangan undang-undang } \\
\text { itu tidak boleh diajukan lagi dalam } \\
\text { persidangan Dewan Perwakilan } \\
\text { Rakyat masa itu. }\end{array}$ & $\begin{array}{l}\text { (3) Jika suatu rancangan undang- } \\
\text { undang tidak mendapat } \\
\text { persetujuan Dewan Perwakilan } \\
\text { Rakyat rancangan tersebut tidak } \\
\text { dapat diajukan lagi dalam } \\
\text { persidangan Dewan Perwakilan } \\
\text { Rakyat masa itu. }\end{array}$ \\
\hline $\begin{array}{l}\text { (4) Presiden mengesahkan rancangan } \\
\text { undang-undang yang telah disetujui } \\
\text { bersama untuk menjadi undang- } \\
\text { undang. }\end{array}$ & $\begin{array}{l}\text { (4) Presiden sebagai kepala } \\
\text { pemerintahan mengesahkan } \\
\text { rancangan undang-undang yang } \\
\text { telah disetujui oleh Dewan } \\
\text { Perwakilan Rakyat selambat- } \\
\text { lambatnya tiga puluh hari untuk } \\
\text { menjadi undang-undang. }\end{array}$ \\
\hline $\begin{array}{l}\text { (5) Dalam hal rancangan undang- } \\
\text { undang yang telah disetujui bersama } \\
\text { tersebut tidak disahkan oleh } \\
\text { Presiden dalam waktu tiga puluh } \\
\text { hari semenjak rancangan undang- } \\
\text { undang tersebut disetujui, } \\
\text { rancangan undang-undang tersebut } \\
\text { sah menjadi undang-undang dan } \\
\text { wajib diundangkan. }\end{array}$ & $\begin{array}{l}\text { (5) Jika dalam waktu selambat- } \\
\text { lambatnya tiga puluh hari } \\
\text { Presiden tidak mengesahkan } \\
\text { rancangan undang-undang dan } \\
\text { tidak dikembalikan kepada } \\
\text { Dewan Perwakilan rakyat, maka } \\
\text { rancangan undang-undang } \\
\text { tersebut menjadi undang-undang. }\end{array}$ \\
\hline & $\begin{array}{l}\text { (6) Jika dalam waktu selambat- } \\
\text { lambatnya tigapuluh hari } \\
\text { Presiden tidak mengesahkan } \\
\text { rancangan undang-undang dan } \\
\text { dikembalikan kepada Dewan } \\
\text { Perwakilan Rakyat beserta } \\
\text { dengan } 4 \\
\text { keberatannya, maka Dewan }\end{array}$ \\
\hline
\end{tabular}




\begin{tabular}{|l|l|}
\hline & $\begin{array}{l}\text { Perwakilan Rakyat wajib untuk } \\
\text { membahas kembali rancangan } \\
\text { undang-undang tersebut. }\end{array}$ \\
\hline & (7) $\begin{array}{l}\text { Rancangan undang-undang yang } \\
\text { dikembalikan kepada Dewan }\end{array}$ \\
Perwakilan Rakyat dibahas \\
selambat-lambatnya dalam \\
waktu tiga puluh hari dan harus \\
disetujui oleh minimal 2/3 \\
anggota Dewan Perwakilan \\
Rakyat untuk mendapatkan \\
pengesahan Presiden. \\
\hline
\end{tabular}

Ketiga, menegaskan kewenangan Presiden sebagai Kepala Negara dan sebagai Kepala Pemerintahan. Konstruksi politik sistem presidensil tidak mengenal pembedaan dan pemisahan antara kedudukan sebagai Kepala Negara dan kepala pemerintahan (Yuda, 2010: 259). Artinya, kedudukan sebagai Kepala Negara dan kepala pemerintahan menyatu dalam satu jabatan Presiden. Hal ini tentu sangat berbeda dengan sistem parlementer yang membedakan dan memisahkan kedudukan sebagai Kepala Negara dan kepala pemerintahan.

Meskipun tidak dibedakan mengenai kedudukan sebagai Kepala Negara dan kepala pemerintahan, tugas dan wewenang Presiden sebagai Kepala Negara dan kepala pemerintahan haruslah diatur secara tegas dalam konstitusi. Namun, UUD NRI 1945 tidak secara tegas menyebutkan kapan seorang Presiden menjalankan kewenangannya sebagai Kepala Negara dan kapan seorang Presiden menjalankan kewenangannya sebagai kepala pemerintahan. UUD NRI 1945 hasil perubahan keempat hanya menyebut Presiden sebagai Kepala Pemerintahan sebagaimana termuat dalam Pasal 4 ayat 1.

Oleh karena itu, penulis mengusulkan untuk mempertegas tugas dan wewenang Presiden sebagai Kepala Negara dan Kepala Pemerintahan dengan menambahkan kalimat "Kepala Negara" dalam Pasal 4 ayat 1. Sehingga redaksi pasal yang diusulkan penulis dalam Pasal 4 ayat 1 adalah "Presiden memegang kekuasaan sebagai Kepala Negara dan kepala pemerintahan menurut Undang-Undang Dasar". Selain itu, penegasan tersebut juga memudahkan masyarakat awam dalam membaca dan memahami konstitusi.

Kemudian sebagai konsekuensi logis dari penyebutan Kepala Negara dalam Pasal 4 ayat (1) UUD NRI 1945, maka pasal-pasal dalam konstitusi yang berhubungan dengan kedudukan Presiden dalam menjalankan kewenangannya akan dipertegas dengan penyebutan sebagai Kepala Negara dan Kepala Pemerintah. Untuk memperjelas usulan tersebut, berikut akan disebutkan usulan penyusun terkait kedudukan Presiden sebagai Kepala Negara dan kepala pemerintahan dalam pasal-pasal UUD NRI 1945: 


\section{a. Presiden sebagai Kepala Negara:}

1) Presiden sebagai Kepala Negara memegang kekuasaan yang tertinggi atas Angkatan Darat, Angkatan Laut, dan Angkatan Udara (Pasal 10).

2) Presiden sebagai Kepala Negara dengan persetujuan Dewan Perwakilan Rakyat menyatakan perang, membuat perdamaian, dan perjanjian dengan negara lain (Pasal 11 ayat (1)).

3) Presiden sebagai Kepala Negara dalam membuat perjanjian internasional lainnya yang menimbulkan akibat yang luas dan mendasar bagi kehidupan rakyat yang terkait dengan beban keuangan negara, dan/atau mengaharuskan perubahan atau pembentukan undang-undang harus persetujuan Dewan Perwakilan Rakyat (Pasal 11 ayat (2)).

4) Presiden sebagai Kepala Negara menyatakan keadaan bahaya yang syarat-syarat dan akibatnya ditetapkan dengan undang-undang (Pasal 12).

5) Presiden sebagai Kepala Negara memberikan grasi, amnesti, abolisi dan rehabilitasi (Pasal 14 ayat 1 dan 2).

6) Presiden sebagai Kepala Negara memberi gelar, tanda jasa, dan lainlain tanda kehormatan yang diatur dengan undang-undang (Pasal 15).

\section{b. Presiden sebagai Kepala Pemerintahan.}

1) Presiden sebagai Kepala Pemerintahan berhak mengajukan rancangan undang-undang kepada DPR, baik Rancangan Undang-undang Anggaran Pendapatan dan Belanja Negara atau APBN, maupun non APBN (Pasal 5 ayat 1 ).

2) Presiden sebagai Kepala Pemerintahan menetapkan Peraturan Pemerintah untuk menjalankan Undang-undang (Pasal 5 ayat 2).

3) Presiden sebagai Kepala Pemerintahan berwenang mengangkat dan memberhentikan menteri-menteri negara (Pasal 17 ayat 2).

4) Presiden sebagai Kepala Pemerintahan mengesahkan rancangan undang-undang yang telah disetujui oleh Dewan Perwakilan Rakyat (Pasal 20 ayat 4).

5) Pasal 22 ayat (1) sampai (4) sudah menegaskan kedudukan Presiden sebagai Kepala Pemerintahan, sehingga tidak perlu penambahan kalimat "Presiden sebagai kepala pemerintahan".

Keempat, pengangkatan duta dan konsul dapat langsung dilakukan oleh Presiden tanpa harus didahului dengan pertimbangan DPR. Namun apabila konsultasi tersebut dibutuhkan oleh Presiden, maka Presiden dapat melakukannya. Artinya, pertimbangan DPR terhadap Presiden berkenaan dengan pengangkatan duta dan konsul tidak bersifat mengikat. Adapun alasan yang mendasari usulan ini adalah karena Presiden dalam kewenangannya sebagai Kepala Negara dapat langsung mengangkat duta dan konsul. Hal ini senada dengan Albert Hasibuan yang berpendapat bahwa ketidaksempurnaan UUD NRI 1945 pascaperubahan, berdasarkan fenomena dominasi kekuasaan DPR atau legislative heavy. Salah satu 
bukti pada Pasal 13 ayat (3) UUD NRI 1945, yakni Presiden menerima penempatan duta negara lain dengan memeperhatikan pertimbangan DPR. Biasanya kewenangan menerima duta negara lain adalah domain eksekutif atau Presiden, maka ketentuan adanya pertimbangan DPR menunjukkan dominasi kekuasaan DPR yang telah memasuki domain Presiden (Hasibuan, "Politik: Perubahan ke 5 UUD", (http://www.slideshare.net/AritonagKurus/perubahan-kelima-uud-1945), diakses pada 1 Desember 2016).

Kelima, meskipun upaya pemurnian sistem pemerintahan presidensil dalam konteks ini cakupannya bukan pada tatanan UUD NRI 1945, namun menjadi perlu untuk diperhatikan bahwa upaya lain yang dapat kita lakukan guna memurnikan sistem pemerintahan presidensil adalah dengan melakukan penyederhanaan terhadap partai politik. Hal ini dikarenakan bahwa perpaduan antara sistem pemerintahan presidensil dan sistem multipartai bukanlah pasangan yang serasi untuk mengasilkan sistem presidensial yang efektif. Jika terus dipaksakan maka sistem presidensial akan menjadi lemah dan memperburuk kondisi pemerintahan. Mekanisme yang digunakan untuk menyederhanakan partai politik dari multi partai ekstream menuju ke multi partai sederhana atau bahkan untuk mendapatkan dua partai besar yang bersaing dalam pemilu, digunakan mekanisme ambang batas atau sering disebut dengan threshold (Al-Arif, 2015: 254).

\section{Kedudukan Kamar Parlemen di Indonesia (Gagasan Penguatan Sistem Bicameral)}

Sebelum dilakukanya perubahan ketiga terhadap UUD NRI 1945, di tingkatan pusat dikenal adanya dua badan perwakilan rakyat yakni MPR dan DPR. Dengan adanya dua badan perwakilan tersebut, tidak sedikit para ahli yang kemudian berpendapat bahwa Indonesia menganut sistem parlemen dua kamar (bicameral). Inilah kemudian yang menjadi awal kesalahan dalam berfikir ketika itu. Dengan sistem ketatanegaraan Indonesia yang demikian, tidaklah berarti bahwa negara Indonesia menganut parlemen bicameral. Hal ini dikarenakan MPR dan DPR mempunyai fungsi yang berbeda (Thaib, 2002: 10). Fungsi dan kewenangan MPR ketika itu adalah menetapkan UUD NRI 1945 dan Garis-Garis Besar Haluan Negara (GBHN) serta memilih Presiden dan Wakil Presiden (Pasal 3 dan Pasal 6 ayat 2 UUD NRI 1945). Sementara fungsi dan kewenangan DPR adalah menyusun UndangUndang (UU), mengawasai pemerintah, dan menetapkan Anggaran Pendapatan dan Belanja Negara (APBN) bersama Presiden.

Kenyataan bahwa Indonesia menganut parlemen dua kamar (bicameral) sebenarnya baru terlihat ketika dilakukannya perubahan ketiga terhadap UUD NRI 1945 oleh MPR dalam Sidang Tahunan MPR tahun 2001 yang menghapuskan MPR sebagai lembaga negara tertinggi dan membentuk DPD sebagai lembaga yang dianggap mampu merepresentasikan perwakilan rakyat/daerah. Dengan fungsi DPD yang menyerupai DPR dalam hal legislasi, anggaran, dan pengawasan, menjadikannya sebagai kamar tersendiri selain DPR. Inilah kemudian yang dinamakan sebagai sistem parlemen dua kamar (bicameral) dalam ketatanegaraan Indonesia. Lantas timbul sebuah pertanyaan bahwa bagaimana dengan MPR? 
Dahlan Thaib telah menjelaskan bahwa MPR tidaklah dapat dimaknai sebagai lembaga karena dalam kenyataanya MPR merupakan sidang gabungan (join session) antara kedua lembaga legislatif yang menjadi bagian daripada kamar yang berbeda tersebut. Dalam pidato pengukuhan jabatan Guru Besar Madya Hukum Tata Negara yang disampaikan di depan Sidang Senat Terbuka Universitas Islam Indonesia (UII) pada tanggal 4 Mei 2002, Dahlan Thaib mengatakan (Thaib, 2002: 10):

"Di dalam menjalankan fungsi dan wewenangnya, kedua badan legislatif itu (DPR dan DPD) berjalan sendiri-sendiri, tetapi bisa juga bersidang bersama untuk membahas persoalan yang dianggap penting. Persidangan bersama antara badan legislatif itulah yang disebut sebagai MPR. Dengan demikian, dengan dihapusnya MPR sebagai lembaga, keberadaan MPR tetap diperlukan, yaitu sebagai forum bersama antara DPR dan DPD. Dengan kata lain, MPR sebagai forum dan bukan sebagai lembaga, maka MPR tidak perlu lembaga, tetapi hanya merupakan sidang gabungan (join session) antara kedua lembaga legislatif. Adapun ketua sidang dalam gabungan itu, dipilih berdasarkan kesepakatan anggota dari dua badan legislatif tersebut."

Akan tetapi, ide bicameralisme atau struktur parlemen dua kamar tersebut mendapat tentangan yang keras dari kelompok-kelompok konservativ di Panitia Ad Hoc Perubahan UUD NRI 1945 di MPR 1999-2002, sehingga yang disepakati adalah rumusan yang sekarang tidak dapat disebut menganut sistem parlemen dua kamar (bicameral) sama sekali (Asshiddiqie, 2012: 126).

Hal senada dikemukakan oleh Jimly Asshiddiqie, ia menganggap dengan keadaan ketatanegaraan yang demikian tidak semata-mata menjadikan negara Indonesia menganut sistem parlemen dua kamar (bicameral), melainkan menganut sistem parlemen tiga kamar (trikameral) karena terdiri atas DPR, DPD dan MPR yang ketiganya dapat dikatakan lembaga yang berdiri sendiri. Untuk mepertegas hal tersebut, ia mengatakan bahwa DPR maupun DPD sama sekali tidak menjadi cakupan dari kewenangan yang dimiliki oleh MPR sebagaimana termuat dalam Pasal 3 juncto Pasal 8 ayat (2) dan (3), MPR mempunyai kewenangan untuk (1) mengubah dan menetapkan Undang-Undang Dasar; (2) memberhentikan Presiden dan/atau wakil Presiden dalam masa jabatannya menurut Undang-Undang Dasar; (3) memilih Presiden dan/atau Wakil Presiden untuk mengisi kekosongan dalam jabatan Presiden dan/atau Wakil Presiden menurut Undang-Undang Dasar; dan (4) mengadakan sidang MPR untuk mengucapkan sumpah/janji jabatan Presiden dan/atau Wakil Presiden. Sehingga ia menafsirkan bahwa sidang MPR untuk mengambil keputusan mengenai keempat hal tersebut sama sekali bukanlah sidang gabungan antara DPR dan DPD melainkan sidang MPR sebagai lembaga tersendiri. Inilah kemudian yang dijadikan oleh Jimly Asshiddiqie sebagai argumen penguat untuk mengatakan bahwa sistem parlemen yang dianut oleh Indonesia saat ini adalah sistem parlemen tiga kamar (trikameral) (Asshiddiqie, 2012: 126.)

Menanggapi dua pendapat yang berbeda tersebut, penulis dapat berkesimpulan bahwa telah terjadi kesalahan penafsiran terhadap UUD NRI 1945 yang dalam perjalanannya berimplikasi pada tidak adaannya kepastian kedudukan ketatanegaraan Indonesia, berkayuh antara sistem bicameral ataukah trikameral. 
Ketidakpastian tersebut kemudian berpengaruh terhadap kinerja DPD dan hubungan kelembagaan antara DPD dengan DPR maupun DPD dengan Presiden (Huda, 2008: 384). Pilihannya sekarang adalah apakah kita akan memperjelas kedudukan MPR sebagai sebuah lembaga yang permanen dalam artian kita menyatakan diri sebagai negara yang berlandaskan parlemen tiga kamar (trikameral) ataukah menghilangkan tafsir bahwa MPR merupakan lembaga yang memiliki anggota tersendiri dalam sistem ketatanegaraan dalam artian kita menyatakan secara tegas sebagai negara yang berlandaskan parlemen dua kamar (bicameral). Karena hanya dengan begitulah negara ini akan terbebaskan dari belenggu ketidakpastian jalan mana yang akan dipilih.

Menilik kembali pada pendapat yang dikemukakan oleh Dahlan Thaib bahwa negara Indonesia tidak dapat dikatakan menganut parlemen dua kamar (bicameral) karena berbedanya fungsi yang dimiliki oleh MPR maupun DPR. Secara sederhana dapat disimpulkan bahwa ketika kita ingin menjadikan suatu lembaga menjadi beberapa kamar yang berbeda, lembaga tersebut haruslah memiliki fungsi yang sama. Ketika kita benturkan dengan masa kekinian, menjadi tidak mungkin memaksakan MPR yang notabennya tidak memiliki fungsi yang sama halnya dengan DPR dan DPD untuk bersama-sama menduduki tiga kamar yang berbeda. Maka dapat dimaknai bahwa dengan keadaan yang demikian, Indonesia tidaklah dapat dimaknai sebagai negara yang menganut parlemen tiga kamar (trikameral). Karena di antara ketiga tersebut (MPR, DPR, dan DPD), MPR tidaklah memiliki fungsi yang sama dengan DPR maupun DPD. Sehingga tepatlah jika kita mempertegas bahwa negara Indonesia menganut parlemen dua kamar (bicameral), dengan DPR sebagai kamar satu dan DPD di kamar lainnya.

Sebagai konsekuensi atas hal tersebut, langkah pertama yang harus dilakukan dalam upaya memperkuat sistem bicameral adalah menghilangkan kata "anggotaanggota" dalam komposisi keanggotaan MPR agar tidak ada lagi tafsir yang mengatakan bahwa MPR merupakan lembaga sendiri yang memiliki anggota. Karena dengan susunan kata yang menyebutkan "MPR terdiri dari anggota-anggota DPR dan DPD" tidaklah menggambarkan bahwa negara Indonesia menganut parlemen dua kamar (bicameral). Sebaliknya, ketika kita melakukan perubahan susunan MPR yang semula terdiri dari anggota-anggota DPR dan DPR menjadi “MPR terdiri dari DPR dan DPD”, hal tersebut menegaskan tafsir bahwa negara Indonesia menganut parlemen dua kamar (bicameral).

Hal ini diperkuat oleh Ni'matul Huda yang mengatakan bahwa dalam susunan dua kamar, bukan anggota yang menjadi unsur, tetapi badan yaitu DPR dan DPD. Seperti Congress Amerika Serikat yang terdiri dari Senate dan House of representatives. Jika anggota yang menjadi unsur, maka MPR adalah badan yang berdiri sendiri di luar DPR dan DPD (Huda, 2008: 384). Berikut adalah redaksi yang harus dilakukan perubahan dalam UUD NRI 1945: 


\begin{tabular}{|c|c|}
\hline Ius Contitutum: & Ius Contituendum: \\
\hline Pasal 2 ayat (1) & Pasal 2 ayat (1) \\
\hline $\begin{array}{l}\text { "Majelis Permusyawaratan } \\
\text { terdiri atas anggota } \\
\text { Perwakilan Rakyat dan anggota } \\
\text { Dewan Perwakilan Daerah yang } \\
\text { dipilih melalui pemilu dan lebih lanjut } \\
\text { diatur dalam undang-undang." }\end{array}$ & $\begin{array}{l}\text { "Majelis Permusyawaratan Rakyat } \\
\text { terdiri atas Dewan Perwakilan Rakyat } \\
\text { dan Dewan Perwakilan Daerah yang } \\
\text { dipilih melalui pemilihan umum dan } \\
\text { lebih lanjut diatur dalam undang- } \\
\text { undang". }\end{array}$ \\
\hline
\end{tabular}

Konsekuensi lain atas hal tersebut adalah perlu suatu nama bagi badan perwakilan yang mencerminkan unsur perwakilan tersebut, seperti Congress sebagai nama badan perwakilan yang terdiri dari Senate dan House of Representative. Nama yang digagas untuk badan perwakilan dua kamar di Indonesia adalah tetap menggunakan Majelis Permusyawaratan Rakyat (MPR). Sebagai konsekuensi penggunakaan nama MPR sebagai nama sistem dua kamar, dengan begitu MPR tidak lagi menjadi suatu lingkungan jabatan yang memiliki wewenang sendiri. Wewenang MPR (baru) melekat pada wewenang DPR dan DPD, atau seperti dalam UUD Amerika Serikat dan lain-lain negara dengan sistem dua kamar, yang tentunya adalah wewenang Congress, Parliament, Staten Generaal yang pelaksanaannya dilakukan oleh kamar-kamar perwakilannya (Manan, 2006: 54).

Lebih lanjut, agar parlemen dua kamar (bicameral) yang penulis gagas ini benar-benar menjadi ideal, DPD dan DPR haruslah diposisikan dalam strata yang sama. Jangan sampai ada satu di antara dua lembaga tersebut yang justru terlihat hanya sebagai lembaga penunjang atau auxiliary. Seperti yang terjadi saat ini, DPD dalam konstruksi UUD NRI 1945 terlihat sebagai lembaga yang bertugas untuk menunjang DPR dalam bidang legislasi. Fenomena demikian itu membuat DPD paling jauh hanya dapat disebut sebagai co-legislator, daripada legislator yang sepenuhnya (Huda, 2008: 207).

Oleh karenanya, agar cita bicameral dapat terwujudkan di Indonesia, penguatan fungsi dan kewenangan DPD menjadi suatu keharusan. Namun begitu, kita juga harus memperhatikan bahwa meskipun kedudukan dan fungsi antara DPR dan DPD adalah sama, tetapi tetap perlu diberikan suatu pembedaan dalam beberapa hal, misalnya saja terkait tugas pembahasan dan pengesahan rancangan undang-undang (Thaib, 2002:18).

Untuk itu, upaya yang dapat dilakukan untuk melakukan penguatan terhadap DPD guna mewujudkan Indonesia dengan sistem parlemen dua kamar (bicameral) adalah: pertama, terkait fungsi legislasi. Telah dikatakan sebelumnya bahwa posisi DPD dalam konstruksi UUD NRI 1945 berkenaan dengan fungsi legislasi lebih terlihat sebagai penunjang atau auxiliary terhadap DPR, sehingga DPD paling jauh hanya dapat disebut sebagai co-legislator, daripada legislator yang sepenuhnya. Oleh 
karena itu menjadi logis sekiranya DPD diberikan kewenangan untuk ikut membahas dan memutus terhadap rancangan undang-undang. Tetapi meskipun demikian, harus diingat bahwa antara DPR dan DPD haruslah diberikan suatu pembeda. Terdapat beberapa skenario pemberdayaan DPD dalam hal fungsi legislasi yang diusulkan sejumlah ahli dan politisi: (1) dalam bidang legislasi kedudukan DPD tidak perlu sepenuhnya setara atau sama luasnya dengan DPR; (2) kewenangan legislatif DPD cukup terbatas pada bidang-bidang yang sekarang sudah tercantum dalam UUD NRI 1945 dan itu pun tetap bersama dengan DPR; (3) kewenangan legislasi DPD dirumuskan dengan berbagai cara, seperti di negara-negara lain, mulai dari hak menolak (veto), mengembalikan ke DPR, atau hanya menunda; (4) kewenangan pengawasan DPD memiliki kekuatan hukum sama dengan DPR agar fungsi pengawasan efektf.

Dari empat sekenario tersebut, penulis melihat bahwa skenario pertama adalah pilihan yang tepat untuk diterapkan dalam sistem ketatanegaraan Indonesia. Hal ini dikarenakan DPD merupakan lembaga yang memang didesain berbeda dengan DPR, terutama di bidang legislasi. Pemberian kewenangan legislasi bagi DPD tentu saja dirancang tidak sama persis dengan DPR, mengingat bahwa hakikat dari DPD memang sebagai kamar yang berbeda dari DPR sehingga kewenangannya berbeda. Perbedaan tersebut adalah: (1) pelibatan DPD dalam persetujuan perjanjian internasional yang diajukan Presiden untuk dijadikan UU ratifikasi. Tidak semua persetujuan DPD dilakukan untuk semua perjanjian internasional. Hanya perjanjian-perjanjian internasional yang menyangkut daerah yang memerlukan persetujuan DPD. Misalnya mengenai perjanjian internasional tentang eksplorasi sumber daya alam yang berada di daerah. (2) penguatan DPD dalam bidang legislasi adalah penambahan kewenangan DPD dalam pembuatan UU yang berkaitan dengan daerah. Penambahan tersebut adalah dengan menambah persyaratan bahwa dalam membuat UU atau legislasi membutuhkan pembahasan dan persetujuan dari DPD bersama dengan DPR.

Kedua, terkait keanggotaan DPD yang belum memperlihatkan perimbangan di antara keduanya sehingga mekanisme checks and balances di antara dua kamar tersebut dirasa tidak akan berjalan secara efektif. Dalam perubahan ketiga UUD NRI 1945 ditegaskan bahwa anggota DPD dari setiap provinsi jumlahnya sama. Jika dikalkulasikan, jumlah anggota DPD tersebut tidak lebih dari sepertiga jumlah aggota DPR. Selisih jumlah tersebut kemudian berimplikasi pada saat menentukan quorum dalam sidang MPR. Bila diterapkan ketentuan one man one vote (satu orang satu suara), berarti DPR dapat mengabaikan kehadiran DPD. Artinya forum MPR tidak memerlukan persetujuan DPD karena jumlah DPR yang menjadi mayoritas.

Menanggapi hal tersebut, dalam praktek ketatanegaraan jangka panjang perlu dipertimbangkan agar komposisi anggota DPD ditambah dengan mempergunakan sistem bukan jumlahnya sama setiap provinsi, melainkan jumlah anggota DPD disesuaikan dengan persebaran penduduk di suatu provinsi tertentu. Sebagai perbandingan, di Amerika Serikat, senat setiap anggota bagian memiliki 2 orang senator untuk mewakili mereka dalam senat, tidak tergantung dari luas daerah dan 
jumlah penduduk di negara bagian tersebut. Para senator dipilih melalui pemilu lokal dan memiliki jabatan selama 6 tahun. Penggantian senator tidak dilakukan serentak. Setiap 2 tahun sekali diadakan pemilihan anggota senat, di mana 1/3 dari anggota senat habis masa jabatannya dan diganti dengan anggota baru (Sinamo, 2010: 138-139). Perlu diingat, perbaikan dalam hal keterwakilan daerah lewat DPD menjadi sesuatu hal yang perlu. Dengan begitu, sistem dua kamar (bicameral) ini bisa saling mengisi, mengimbangi, dan menjaga (checks and balances) antar lembaga perwakilan.

Ketiga, berkaitan dengan pemaknaan MPR sebagai sebuah forum antara DPD dan DPR. Implikasi dari hal tersebut secara tidak langsung membuat kewenangan yang semula berada pada MPR kini melekat pada DPR dan DPD. Oleh karena itu sudah semestinya DPD memiliki kewenangan dalam hal mengubah dan menetapkan UUD NRI 1945, melantik Presiden dan/atau Wakil Presiden serta usul pemberhentian Presiden dan/atau Wakil Presiden yang seluruhnya harus dilakukan bersama DPR dalam Sidang Majelis Permusyawaratan Rakyat.

Itulah beberapa usulan ataupun gagasan yang dapat penulis ajukan berkenaan dengan pemurnian sistem bicameral di Indonesia. Perlu diketahui bahwa pada dasarnya, seluruh gagasan ini berangkat dari suatu keinginan penulis untuk menjadikan sistem ketatanegaraan Indonesia lebih baik ke depannya. Menjadikan sistem ketatanegaraan Indonesia lebih baik ke depannya haruslah dimaknai sebagai ikhtiar untuk mewujudkan tujuan nasional sebagaimana yang termuat dalam pembukaan UUD NRI 1945, yakni "memajukan kesejahteraan umum, mencerdaskan kehidupan bangsa, dan ikut melaksanakan ketertiban dunia yang berdasarkan kemerdekaan, perdamaian abadi, dan keadilan sosial".

\section{KESIMPULAN DAN SARAN}

\section{Kesimpulan}

Pada dasarnya, gagasan perubahan ulang terhadap UUD NRI 1945 dilakukan karena konstruksi UUD NRI 1945 masih jauh dari ruh konstitusionalisme. Hal tersebut terlihat pada pelaksanaan sistem presidensil yang belum berjalan secara tegas dan tidak adanya kepastian kedudukan ketatanegaraan Indonesia apakah berkayuh pada sistem bicameral ataukah trikameral. Untuk mempertegas sisem presidensil dan memperjelas kedudukan sistem parlemen tersebut, maka perubahan ulang UUD NRI 1945 menjadi suatu keharusan.

Dalam rangka memurnikan sistem pemerintahan presidensil, hal yang harus dilakukan adalah pertama, mencabut kewenangan legislasi yang dimiliki Presiden. Kewenangan legislasi yang dimaksud adalah kewenangan badan legislatif dalam membentuk dan membahas undang-undang yang menjadi kewenangannya secara mutlak; kedua, agar terdapat suatu mekanisme check and balance antara Presiden dan DPR dalam melaksanakan fungsi legislasi, Presiden diberikan hak veto atas rancangan undang-undang yang telah disetujui oleh DPR dengan berbagai persyaratan yang telah ditentukan; ketiga, menegaskan kewenangan Presiden sebagai Kepala Negara dan sebagai Kepala Pemerintahan sebagai identitas 
presidensialisme yang dianut oleh negara Indonesia; keempat, menghilangkan kewajiban Pesiden untuk meminta pertimbangan DPR dalam pengangkatan duta dan konsul; dan kelima, melakukan penyederhanaan terhadap partai politik.

Sementara berkaitan dengan ketidakjelasan kedudukan sistem parlemen di Indonesia, berdasarkan kajian yang telah penulis lakukan, disimpulkan bahwa sebenarnya konstruksi yang dibangun pada kamar parlemen Indonesia menggunakan konsep dua kamar parlemen (bicameral) yang terdiri dari DPR dan DPD. Namun dalam pelaksanaannya, sistem bicameral tersebut ternyata juga belum mampu berjalan secara tegas. Untuk menegaskan sistem bicameral tersebut, langkah pertama yang harus dilakukan adalah merubah paradigma MPR yang semula dianggap sebagai sebuah lembaga yang memiliki keanggotaan tersendiri, menjadi MPR yang merupakan forum sidang gabungan antara DPR dan DPD.

\section{Saran}

Selanjutnya, agar sistem bicameral yang penulis gagas menjadi lebih ideal, DPR dan DPD haruslah diposisikan dalam strata yang sama dalam hal fungsi dan kewenangannya. Jangan sampai ada satu diantara dua lembaga tersebut justru terlihat hanya sebagai lembaga penunjang atau auxiliary seperti halnya yang terjadi saat ini. Oleh karenanya, penguatan fungsi dan kewenangan DPD menjadi suatu keharusan. Penguatan tersebut meliputi pertama, berkaitan dengan fungsi legislasi; kedua, terkait dengan keanggotaan DPD; dan ketiga melekatkan kewenangan MPR ke dalam kelembagaan DPR dan DPD.

\section{DAFTAR PUSTAKA}

\section{A. BUKU, MAKALAH, DAN JURNAL}

Akbar, Patrialis (2013) Hubungan Lembaga KePresidenan Dengan Dewan Perwakilan Rakyat Dan Veto Presediden. Jakarta: Total Media

Al-Arif, Yasin (2015). Anomali Sistem Pemerintahan Presidensial Pasca Perubahan UUD 1945, Jurnal Ius Quia Iustum, Vol. 22, No. 2.

Asshiddiqie, Jimly (2011). Konstitusi dan Konstitusionalisme Indonesia. Jakarta: Sinar Grafika.

(2012). Perkembangan dan Konsolidasi Lembaga Negara Pasca Reformasi. Jakarta: Sinar Grafika.

Budiardjo, Miriam (2008) Dasar-Dasar Ilmu Politik. Jakarta: PT Gramedia Pustaka Utama.

Harjono (2008). Konstitusi Sebagai Rumah Bangsa Pemikiran Hukum Dr. Harjono, Jakarta: Sekretariat Jenderal dan Kepaniteraan Mahkamah Konstitusi.

Huda, Ni'matul (2004). Politik Ketatanegaraan Indonesia: Kajian terhadap Dinamika Perubahan UUD 1945, Yogyakarta: FH UII Press. (2008). UUD 1945 dan Gagasan Perubahan Ulang, Jakarta: PT Raja Grafindo Persada.

(2010). Gagasan Perubahan (ulang) UUD 1945 (usalan untuk 
penguatan DPD dan Kekuasaan Kehakiman), Jurnal Konstitusi, Vol. 7, No. 5.

Indrayana, Denny (2008). Negara Antara Ada dan Tiada Reformasi Hukum Ketatanegaraan. Jakarta: Kompas.

Majelis Permusyawaratan Rakyat (2004). Buku I: Naskah Akademik Kajian Komprehensif Komisi Konstitusi tentang Perubahan Undang-undang Dasar Negara Republik Indonesia Tahun 1945, Jakarta: MPR RI.

Manan, Bagir (2006). Teori dan Politik KonstitusiI. Jakarta: Konstitusi Press.

Marzuki, Laica (2010. Konstitusi dan Konstitusionalisme. Jurnal Konstitusi, Vol. 7, No. 4.

Saraswati, Retno (2012). Desain Sistem Pemerintahan Presidensial yang Efektif, MMH, Jilid 41.

Siahan, Pataniari (2012). Politik Hukum Pembentukan Undang-Undang Pasca Perubahan UUD 1945. Jakarta: Konpress.

Sinamo, Nomensen (2010). Perbandingan Hukum Tata Negara. Jakarta: Permata Aksara.

Suharto, Susilo (2006). Kekuasaan Presiden Republik Indonesia dalam Periode Berlakunya Undang-Undang Dasar 1945. Yogyakarta: Penerbit Graha Ilmu. 2006

Thaib, Dahlan (2002). Menuju Parlemen Bikameral (Studi Konstitusional Perubahan Ketiga UUD 1945). Yogyakarta: FH UII Press.

Yuda, Hanta (2010). Presidensialisme Setengah Hati. Jakarta: PT Gramedia Pusaka Utama.

\section{B. PERATURAN PERUNDANG-UNDANGAN}

Undang-Undang Dasar Negara Republik Indonesia Tahun 1945

\section{INTERNET}

http://www.slideshare.net/AritonagKurus/perubahan-kelima-uud-1945 http://www.jimly.com/makalah/namafile/123/SISTEM PRESIDENTIL.pdf http://repository.usu.ac.id/bitstream/123456789/18016/4/Chapter\%20I.pdf 